\title{
Drivers of technological capability in Mexico: The mesoeconomic factors that impulse the techno-scientific products
}

\author{
Determinantes de la capacidad tecnológica en México: factores \\ meso económicos que impulsan los productos tecno-científicos \\ Carla Carolina Pérez Hernández* \\ Universidad Autónoma del Estado de Hidalgo, México \\ Received May 30, 2018; accepted November 13, 2018 \\ Available online December 14, 2018
}

\begin{abstract}
The aim of this paper is to examine the impact of technological inputs and the preconditions for development on the results achieved in terms of technological capacity in Mexico (measured by granted patents, publications and high complexity exports). Consequently, a panel data technique was applied with individual and temporal fixed effects, based on the variables proposed by Cepal (2007) \& Hausmann \& Nedelkoska (2018), and collecting data from various public sources. From the econometric estimation, it is found that: the imports of highly complex products, education investment, international immigration and the number of researchers are drivers of technological capacity that show the greatest impact for impulse the techno-scientific capability of the region.
\end{abstract}

JEL code: $\mathrm{O} 10, \mathrm{O} 30, \mathrm{O} 31$

Keywords: Technological capability; Data panel; Techno-scientific products

\section{Resumen}

El objetivo del presente trabajo es examinar el grado de impacto que tienen los esfuerzos realizados (inputs) junto con el fortalecimiento de la base disponible (precondiciones para el desarrollo) sobre los

\footnotetext{
*Corresponding author. E-mail address: carolina.cph@gmail.com (C.C. Pérez). Peer Review under the responsibility of Universidad Nacional Autónoma de México. http://dx.doi.org/10.22201/fca.24488410e.2019.2057 0186- 1042/C2019 Universidad Nacional Autónoma de México, Facultad de Contaduría y Administración. This is an open access article under the CC BY-NC-SA (https://creativecommons.org/licenses/by-nc-sa/4.0/)
} 
resultados logrados en materia de capacidad tecnológica en México (medidos en patentes otorgadas, publicaciones y exportaciones de alta complejidad). Para ello, se aplicó la técnica de datos de panel con efectos fijos individuales y temporales, con base en las variables propuestas por Cepal (2007) \& Hausmann \& Nedelkoska (2018), y recopilando los datos de diversas fuentes públicas. A partir de la estimación econométrica, se encuentra que: las importaciones de productos de alta complejidad, el gasto en educación, la inmigración internacional y el número de investigadores son los determinantes de la capacidad tecnológica que muestran un mayor impacto para impulsar la capacidad tecno-científica de la región.

Código JEL: O10, O30, O31

Palabras clave: Capacidad tecnológica; Panel de datos; Productos tecno-científicos

\section{Introduction}

Included in the concept of technological capability is the implication of the knowledge and skills needed to acquire, use, absorb, adapt, improve and generate new technologies for the development of new products and processes (Bell and Pavitt, 1995; Lall, 1992). In other words, the technological capability of a nation is measured fundamentally by the knowledge and know-how ${ }^{1}$ of its people. Specifically, a country must have citizens with "know how" to adopt, adapt, improve and innovate new technologies in order to crystallize their imagination ${ }^{2}$ to generate new technological innovations. Moreover, fundamental to technological capability is the absorption capability. It means that in order to adopt and adapt technologies, we must first learn them thoroughly and replicate them consistently. While this capacity impulse the innovation capability -defined as improving and creating new technologies for the marketplace- undoubtedly, the prelude to technological innovation is technological capability which includes the capacity of innovation and absorption.

For this reason, Hidalgo (2017) highlights that learning - the accumulation of knowledge and know-how- always has a geographical bias. Therefore, the subnational assessment of technological capability must first show evidence of its behavior with the goal of avoiding the increase of any geographical bias. This goal can be achieved through the design of differentiated policies that avoid generating greater regional imbalances than those already in existence. The visible problem of technological capability is that, in developing regions, such as Mexico, there is a lack of empirical evidence; that lack of fact-based scrutiny leads, in many cases, to errors among the political, legislative, academic, governmental and entrepreneurial efforts seeking to

\footnotetext{
${ }^{1}$ Understood as tacit knowledge or tacit ability to know-how.

${ }^{2}$ According to Hidalgo (2017), the products we create are crystals of imagination, static concretions of our ideas. Why is "crystal" chosen as a metaphor? A crystal is a statically ordered arrangement of atoms. When we manufacture products, we create tangible and digital objects that contain the solidified or frozen concretion of a process that is much more fluid and dynamic: the imagination.
} 
increase it. By contrast, having a wide range of research in this area allows us to validate and/or correct the efforts made to promote these capabilities at the local, regional, and national levels.

It is important to state that it is not about increasing the technological capabilities just to increase them. Rather, it is about analyzing them to learn what does work and what does not work, to identify the catalyzing and inhibiting factors, and to understand how that capacity is distributed throughout the territories with the fundamental purpose of preventing technological capabilities from widening the inequality gap, and conversely, having the goal of narrowing it. The most dangerous pathology from the inadequate promotion of technological capability is inequality and the increase of the Matthew effect ${ }^{3}$.

Therefore, this paper begins with the assumption of the need to recognize what factors catalyze this capacity. We begin, then, with the following central question: What is the impact (elasticity) of the efforts made and the available base over the technological capability in Mexico?

In order to respond to this question critically, it is important to recognize that research carried out to date on the measurement of technological capacity at the subnational level in Mexico are at an initial stage. Consequently, broader, complementary, and specific analyses are required. Quoting Boisier (1995, p.2) "a more systematic advance towards the development probably supposes putting into practice more and a better method of action in an intermediate level that is to say at mesoeconomic level, in which, the interaction between institutional and personal actors is key. This level has a territorial expression everywhere: it is the (subnational) region, or the province, or the federative state. It is a territorial space smaller than the country, but broader than the mere locality".

This paper is organized accordingly: first, a literature review, then, a discussion of the quantitative methodology used, followed by our analysis of the results and our interpretations, and lastly a summary and conclusions.

\section{Literature review}

According to Arias (2009), the issue of technological capabilities has been addressed in most cases at the microeconomic and descriptive level. Similarly, Torres (2006), finds that there are few studies that have analyzed macro-level capabilities and even fewer those that investigate at the sub-national level.

For their part, Stern, Porter \& Furman (2000, p.32) stress that "the evaluation of the determinants of technological and innovative capability in all regions has a double objective:

\footnotetext{
${ }^{3}$ Albornoz (2001), parallels the Matthew effect: God gives more to the one who has more. In the understanding that, if science, knowledge and capacities have become a force of production, then they mirror the social structure. They become an instrument that can make the rich richer and the poor poorer.

"Matthew 13:11, says enigmatically: Because whoever that has will be given and will have more; but to the one who does not have, even what he has, it will be taken away from him" (Monedero, 2015, p.242).
} 
first, to inform those in charge of science policy and technology and a second purpose is to illuminate the factors that underline the growth of national productivity".

For this reason, numerous empirical studies related to the macro analysis of technological capacity and innovation have been developed in highly industrialized countries, all based mainly on the theory of endogenous development formulated by Romer (1990) and adapted initially in an econometric way by Stern, Porter \& Furman (2000) and replicated or adapted in various industrialized contexts by Baumert \& Heijs (2002); Riddel \& Schwer (2003); Ulku (2004); Faber \& Hesen (2004); Furman \& Hayes (2004); Hu \& Mathews (2008); Gans \& Hayes (2009); Krammer (2009); who have contemplated a sample that includes developed countries of the OECD, regions of USA, European countries, countries of East Asia and China.

In Ibero-America and in developing countries in general, econometric studies are reduced to what was done by Chinaprayoon (2007), which considers only a limited sample of 10 Latin American countries from 1996-2003. In Spain, López, Serrano \& García (2011), consider a sample of 17 autonomous communities during a brief period from 2001 - 2005. Lastly, a study developed by Pérez, Gómez \& Lara (2018), examines the technological capacity of 17 Latin American countries over a more recent time period from 2000 to 2014 . At the regional level in Mexico, Torres (2002) makes a pioneering effort to study the impact of technological globalization on the generation of patents requested during the period from 1996-2000. Similarly, Hernández \& Díaz (2007) conduct a regional analysis of the requested patents (as a proxy for innovation) considering a period that goes from the year 1996 to 1999.

Likewise, Cepal (2007), performs a descriptive statistical study of technological capacity in Latin America, proposing a set of measurements for the technological capabilities for Developing Countries through three dimensions: 1) The available base, that is human resources, infrastructure, 'quality' of the environment, 2) The efforts made to increase and consolidate capacities (inputs), like acquisition of knowledge in its various forms, for example, in Hausmann \& Nedelkoska (2018) immigration implies a mobility input of know-how, investments in R\&D, education, and others, and 3) The results obtained from the existing capacities: patents, scientific publications, rate of innovation and technological content of exports. For Cepal (2007), the technological capacity is then identified by the following equation:

\section{The results achieved $=\boldsymbol{f}$ (the available base, the efforts made)}

Following Cepal (2007), the taxonomy of technological capacity is divided in three dimensions of variables (the available basis, the efforts made, and the results achieved) is introduced for the purposes of this research to provide a framework for empirical testing among the United Mexican States. 
All the variables are listed in table 1 and will be normalized by the population, taking into account the size of the economy of each state. Furthermore, we consider that in most of the previous studies (Stern, Porter, \& Furman, 2000, Ulku, 2004, Chinaprayoon, 2007, Hu and Mathews, 2008, Gans and Hayes, 2009), the models take the Log-Log functional form to achieve minimizing the problems of outliers. Consequently, all the variables are recalculated in Natural Logarithm values ( $\mathrm{Ln}$ ) for the equation (1), except for those variables that are already expressed in percentage values. Both the study dimensions and the variables that make up each dimension can be observed in the next table.

Table 1

Indicators of technological capabilities

\begin{tabular}{|c|c|c|c|c|}
\hline \multicolumn{5}{|c|}{ THE AVAILABLE BASIS } \\
\hline Variable & Name & Definition & $\begin{array}{l}\text { Type of } \\
\text { capacity }\end{array}$ & Source \\
\hline \multicolumn{5}{|l|}{ Acervo de RRHH } \\
\hline $\mathrm{X}_{1:}$ literacy $_{\mathrm{j}, \mathrm{t}}$ & Literacy rate & $\begin{array}{l}\text { The difference between } 100 \% \\
\text { and the rate of illiteracy (the } \\
\text { person of } 15 \text { or more years of } \\
\text { age who cannot read or write } \\
\text { a message) }\end{array}$ & & (SNIE, 2016) \\
\hline $\mathrm{X}_{2:}$ enrol1 ${ }_{\mathrm{j}, \mathrm{t}}$ & $\begin{array}{l}\text { Primary } \\
\text { enrollment rate }\end{array}$ & $\begin{array}{l}\text { Net rate of primary schooling } \\
\text { ( } 6 \text { to } 11 \text { years of age) }\end{array}$ & & \\
\hline $\mathrm{X}_{3:}$ enrol2 ${ }_{\mathrm{j}, \mathrm{t}}$ & $\begin{array}{l}\text { Secondary } \\
\text { enrollment rate }\end{array}$ & $\begin{array}{l}\text { Net Secondary Schooling Rate } \\
\text { (12 to } 14 \text { years old) }\end{array}$ & & (SNIE, 2016) \\
\hline $\mathrm{X}_{4:}$ enrol3 ${ }_{\mathrm{j}, \mathrm{t}}$ & $\begin{array}{l}\text { Tertiary enrollment } \\
\text { rate }\end{array}$ & $\begin{array}{l}\text { Net High School enrollment } \\
\text { rate ( } 15 \text { to } 17 \text { years old) }\end{array}$ & $\begin{array}{l}\text { Capability of } \\
\text { absorption }\end{array}$ & \\
\hline $\mathrm{X}_{5:}$ graduateSTI $_{\mathrm{j}, t}$ & $\begin{array}{l}\text { Graduates in Sci- } \\
\text { ence Technology } \\
\text { Innovation }\end{array}$ & $\begin{array}{l}\text { Number of graduates of } \\
\text { programs related with } \\
\text { engineering, exact sciences, } \\
\text { natural and computer sciences } \\
\text { (per } 10,000 \text { population) }\end{array}$ & & (ANUIES, 2016) \\
\hline $\mathrm{X}_{6:}$ researchers $_{\mathrm{j}, \mathrm{t}}$ & Researchers & $\begin{array}{l}\text { Number of researchers that be- } \\
\text { long to the National Research } \\
\text { System (NRS) in Mexico (per } \\
10,000 \text { population) }\end{array}$ & & $\begin{array}{c}\text { (FCCYT, 2016), (ATLAS- } \\
\text { DELACIENCIA, 2017) }\end{array}$ \\
\hline
\end{tabular}




\begin{tabular}{|c|c|c|c|c|}
\hline \multicolumn{5}{|l|}{ Infrastructure } \\
\hline $\mathrm{X}_{7:}$ cell ${ }_{\mathrm{j}, \mathrm{t}}$ & Cell phones & $\begin{array}{l}\text { Subscriptions to mobile cell } \\
\text { phones per } 100 \text { population }\end{array}$ & & $(\mathrm{IFT}, 2016)$ \\
\hline $\mathrm{X}_{8:}$ tel $\mathrm{j}_{\mathrm{j}, \mathrm{t}}$ & Telephone lines & $\begin{array}{l}\text { Fixed telephone subscriptions } \\
\text { per } 100 \text { population }\end{array}$ & & (SIEMT, 2016) \\
\hline $\mathrm{X}_{9:}$ electric $_{\mathrm{j}, \mathrm{t}}$ & $\begin{array}{l}\text { Electricity con- } \\
\text { sumption }\end{array}$ & $\begin{array}{l}\text { Electricity consumption. } \\
\text { (Gigawatts-hour) per } 100 \\
\text { population }\end{array}$ & & (CFE, 2016) \\
\hline \multicolumn{5}{|c|}{ Complexity of technological demand } \\
\hline $\mathrm{X}_{10:} \mathrm{GDP}_{\mathrm{j}, \mathrm{t}}$ & GDP & $\begin{array}{l}\text { Gross Domestic Product } \\
\text { expressed in millions of pesos } \\
\text { at } 2008 \text { prices }\end{array}$ & $\begin{array}{l}\text { Technological } \\
\text { capability }\end{array}$ & \\
\hline $\mathrm{X}_{11:}$ GDPperCAP $_{\mathrm{j}, \mathrm{t}}$ & GDP per capita & $\begin{array}{l}\text { (GDP in values at constant } \\
2008 \text { prices) / population. } \\
\text { Expressed in pesos. }\end{array}$ & & (INEGI, 2016) \\
\hline \multicolumn{5}{|c|}{ Type of international commercial insertion } \\
\hline $\mathrm{X}_{12:}$ TRADE $_{\mathrm{j}, \mathrm{t}}$ & $\begin{array}{l}\text { Foreign trade of } \\
\text { high complexity } \\
\text { goods }\end{array}$ & $\begin{array}{l}\text { Exports of highly complex } \\
\text { goods + Imports of highly } \\
\text { complex goods (expressed in } \\
\text { dollars per population) }\end{array}$ & & $\begin{array}{c}\text { (Atlas de Complejidad, } \\
\text { 2018) }\end{array}$ \\
\hline \multicolumn{5}{|c|}{ REALIZED EFFORTS } \\
\hline Variable & Name & Definition & $\begin{array}{l}\text { Type of } \\
\text { capacity }\end{array}$ & Source \\
\hline \multicolumn{5}{|l|}{ Human Resources } \\
\hline $\mathrm{X}_{13:}$ spendEDUC $_{\mathrm{j}, \mathrm{t}}$ & $\begin{array}{l}\text { Public Expenditure } \\
\text { on education }\end{array}$ & $\begin{array}{l}\text { Educational funding per capita } \\
\text { applied by the state and the } \\
\text { federation at all educational } \\
\text { levels. Expressed in pesos. }\end{array}$ & \multirow{4}{*}{$\begin{array}{l}\text { Capability of } \\
\text { innovation }\end{array}$} & (SEP, 2016) \\
\hline & & & & \\
\hline \multicolumn{3}{|l|}{ Innovation efforts } & & \\
\hline $\mathrm{X}_{14:}$ budget $_{\mathrm{j}, \mathrm{t}}$ & $\begin{array}{l}\text { State Budget for } \\
\text { Science and Tech- } \\
\text { nology }\end{array}$ & $\begin{array}{l}\text { State Budget of Science Tech- } \\
\text { nology as\% of state budget }\end{array}$ & & (app CTI indicadores, 2016) \\
\hline
\end{tabular}




\begin{tabular}{|c|c|c|c|c|}
\hline \multicolumn{5}{|c|}{ Acquisition of external knowledge } \\
\hline $\mathrm{X}_{15:}$ FDI $_{\mathrm{j}, \mathrm{t}}$ & $\begin{array}{l}\text { Foreign Direct } \\
\text { Investment (FDI) }\end{array}$ & $\begin{array}{l}\text { Foreign Direct Investment per } \\
\text { capita expressed in dollars. }\end{array}$ & \multirow{5}{*}{$\begin{array}{l}\text { Technological } \\
\text { capability }\end{array}$} & (INEGI, 2017) \\
\hline $\mathrm{X}_{16:}$ import $\% \mathrm{HCP}_{\mathrm{j}, \mathrm{t}}$ & $\begin{array}{l}\text { Imports of high } \\
\text { complexity } \\
\text { products }\end{array}$ & $\begin{array}{l}\text { Imports of highly complex } \\
\text { products (as\% of total } \\
\text { imports) }\end{array}$ & & $\begin{array}{c}\text { (Atlas de Complejidad, } \\
\text { 2018) }\end{array}$ \\
\hline $\mathrm{X}_{17}$ : Inmigra_state ${ }_{\mathrm{j}, \mathrm{t}}$ & $\begin{array}{l}\text { Interstate immi- } \\
\text { gration }\end{array}$ & $\begin{array}{l}\text { People who change their } \\
\text { habitual residence from a } \\
\text { federative entity, in a given } \\
\text { year, viewed from the point of } \\
\text { view of the place of arrival. } \\
\text { (per thousand population). }\end{array}$ & & \multirow{3}{*}{ (CONAPO, 2017) } \\
\hline & & & & \\
\hline $\mathrm{X}_{18:}$ InmigraINT $_{\mathrm{j}, \mathrm{t}}$ & $\begin{array}{l}\text { International } \\
\text { immigration }\end{array}$ & $\begin{array}{l}\text { People who were born in } \\
\text { another country and reside in a } \\
\text { federative entity -México- (per } \\
\text { thousand population). }\end{array}$ & & \\
\hline \multicolumn{5}{|c|}{ RESULTS ACHIEVED } \\
\hline Variable & Name & Definition & $\begin{array}{l}\text { Type of } \\
\text { capacity }\end{array}$ & Source \\
\hline \multicolumn{5}{|l|}{ Patents } \\
\hline $\mathrm{Y}_{1:}$ patentsgranted ${ }_{\mathrm{j}, \mathrm{t}}$ & Patents granted & $\begin{array}{l}\text { Percentage of national patents } \\
\text { granted by state }\end{array}$ & $\begin{array}{l}\text { Capability of } \\
\text { innovation }\end{array}$ & (app CTI indicadores, 2016) \\
\hline \multicolumn{5}{|l|}{ Publications } \\
\hline $\mathrm{Y}_{3:}$ publications $_{\mathrm{j}, \mathrm{t}}$ & $\begin{array}{l}\text { Scientific Publi- } \\
\text { cations }\end{array}$ & $\begin{array}{l}\text { Annual average of indexed } \\
\text { publications of the NRS } \\
\text { researchers }\end{array}$ & \multirow{3}{*}{$\begin{array}{c}\text { Technological } \\
\text { capability }\end{array}$} & (app CTI indicadores, 2016) \\
\hline \multicolumn{3}{|c|}{ Type of commercial insertion: Exports by technological content } & & \\
\hline $\mathrm{Y}_{5:}$ exportcomplex ${ }_{\mathrm{j}, \mathrm{t}}$ & $\begin{array}{l}\text { Complexity prod- } \\
\text { ucts (exported) }\end{array}$ & $\begin{array}{l}\text { Sum of Exports of high and } \\
\text { medium-high complexity } \\
\text { goods. }\end{array}$ & & $\begin{array}{c}\text { (Atlas de Complejidad, } \\
\text { 2018) }\end{array}$ \\
\hline
\end{tabular}

Source: Own elaboration based on the indicators proposed by Cepal (2007) \& Hausmann \& Nedelkoska (2018). 


\section{Methodology}

The methodology of this work consists of developing an econometric analysis to identify the determinants of the technological capacity in Mexico, considering its 32 entities, as a cross-sectional series and using the 2004 to 2016 time period. This analysis is completed in 6 stages: A) Present the descriptive statistics of the variables previously normalized by the size of the population of each state. B) Prepare the matrix of correlations of the independent variables to avoid multicollinearity problems. C) Transform the resulting independent variables and the predetermined dependent variables in Natural Logarithm ( $\mathrm{Ln}$ ) with the exception of those that are expressed as a percentage D) Define the econometric specifications and the base regression model according to equation (1). E) Run the regressions based on the data panel estimation technique with individual and temporary fixed effects. And finally, F) Interpret the results obtained. The mentioned phases will be described in order in the following sections.

\section{Analysis of the descriptive and econometric results Descriptive statistics}

The descriptive analysis is necessary to examine the statistical properties of each variable, besides this analysis allows us to propose the variables and temporality that will be used to evaluate the impact of the technological capacity in the selected states. The total number of observations (N) results from multiplying the time series of 17 years (2000-2016) by the time series of 32 entities, which generally ${ }^{4}$ results in $\mathrm{N}=544$.

In the descriptive statistics of the variables previously normalized by the size of the population, the minimum and maximum, the average, the standard deviation and the coefficient of variation are reported, this is grouped in table 2, some of the main findings are described below:

A) The available base (preconditions for development): With respect to the stock of human resources, reflecting the absorption capacity, it is estimated that on average the literacy rate in Mexico is $92.5 \%$, the average primary enrollment rate It is $98.5 \%$. However, the average percentages decrease when talking about the secondary (77.6\%) and tertiary enrollment rate (47.2\%), which implies that the average net enrollment rate is considerably reduced in the secondary and upper secondary levels, in other words, there are areas of opportunity regarding the enrollment of young people between 12 and 17 years old at the national level. In parallel, it is estimated in the period 2000-2016, for every 10,000 Mexicans there are an average of 8 people entitled in Science Technology and Innovation, likewise, for every 10,000 inhabitants there is an average 1 researcher who is a member of the NRS (National Research System). For

\footnotetext{
${ }^{4}$ For the purposes of descriptive statistics, a temporal series of 17 years (2000-2017) could be counted in most of the variables.
} 
this reason, it is important to emphasize that the number of researchers is the variable with the highest coefficient of variation ( 1.20 global and 1.13 between states), which implies that the dispersion in this case is greater in comparison with the other indicators. Therefore, it can be said that the average number of researchers it is more uneven between states, nevertheless, the coefficient of variation of the number of researcher's decreases to 0.44 along with the standard deviation (0.51) at the moment of executing the calculation over time. Consequently, it can be assumed that the dispersion over time is considerably less than the dispersion between states.

On the other hand, with respect to infrastructure, we estimate that, in the time period being studied, there are on average 73 subscriptions to mobile cell phones per 100 inhabitants (proxy for the diffusion of semi-new technologies), 16 subscriptions to fixed telephone lines per 100 inhabitants and 0.15 (gigawatts-hour) per 100 inhabitants as electricity consumption (proxy for the diffusion of old technologies). These three indicators have a very similar coefficient of variation. Consequently, it can be assumed that their dispersion is very similar. With regard to the complexity of technological demand, on average GDP per capita is $\$ 124,588.61$ pesos per inhabitant. The alarming statistic is that per capita GDP exceeds by 20 times the minimum per capita GDP showing the huge inequality among states. While foreign trade of highly complex goods (sum of imports plus exports of highly complex goods) has an average of $\$ 1,711.90$ per inhabitant.

B) The efforts made: on average, public spending on education is $\$ 3.82$ pesos per inhabitant $^{5}$. Nonetheless, it is noteworthy that in the sample, there are places and times when this expenditure reaches a maximum ceiling of \$ 8.24 pesos per Mexican and a minimum of $\$ 0.58$.

The state budget for science and technology is a variable from which only 156 cross-sectional observations (time and space) could be compiled. From this sample, it reveals that, on average, this budget is $0.17 \%$ of the total state budget. The concerning thing is that its lower limit is $0 \%$, while its upper limit is $1.51 \%$. With respect to the acquisition of external knowledge, the average Foreign Direct Investment (FDI) in the period evaluated was 242.85 dollars per inhabitant; it is also evident that this indicator handles a high dispersion between the states and over time.

Additionally, it is found that on average $36 \%$ of total imports are highly complex imports. The average interstate immigration is 10 people per thousand inhabitants while the international immigration is 2 people per thousand inhabitants on average.

C) The results achieved: The average percentage of granted patents is $3.13 \%$. Moreover, it is observed that this variable is the indicator with the highest coefficient of variation, which denotes the wide dispersion of data between states. Regarding scientific publications, it is found that on average each researcher of the NRS publishes 2 articles indexed annually. While the average percentage of export of highly complex goods is $24 \%$ with respect to total

\footnotetext{
${ }^{5}$ The inhabitants of Mexico City were excluded given the transition from district to city.
} 
exports, nevertheless, the maximum and minimum limits of this variable make it possible to see the enormous gap between the states in terms of exports, exports of medium and high technological content.

Table 2

Descriptive statistics: Mexico (all sample)

Variables N Minimum Maximum Mean $\begin{gathered}\text { Standard } \\ \text { Deviation }\end{gathered} \begin{gathered}\text { Coefficient of } \\ \text { variation }\end{gathered}$

A) Available base

\section{Human resources}

X1: Literacy rate

X2: Primary enrollment rate

$544 \quad 77.10$

98.60

92.49

4.74

0.05

$544 \quad 86.20$

109.14

98.47

3.26

0.03

$\mathrm{X} 3$ : Secondary enrollment rate

544

42.86

106.97

77.62

8.90

0.11

$X 4$ : Tertiary enrollment rate

544

23.20

86.44

47.19

9.92

0.21

X5: Graduates in Science

Technology Innovation

224

2.45

16.34

8.36

3.09

0.37

X6: Researchers NRS

$\mathrm{N}=544$

0.01

9.06

1.37

1.20

$\mathrm{n}=32 \quad 0.15$

6.71

1.14

1.29

1.13

$\mathrm{T}=17$

$-3.39$

3.63

0.51

0.44

\section{Infrastructure}

X7: Cell phones

512

3.90

528.20

73.05

49.45

0.68

X8: Telephone lines

$544 \quad 3.32$

57.93

15.82

7.76

0.49

X9: Electricity consumption

544

0.00

0.39

0.15

0.09

0.62

\section{Complexity of technological demand}

X10: GDP

$$
448
$$

$580,17.41$

$2,365,131.50$

$378,537.35$

$390,844.65$

1.03

X11: GDP per capita

$\mathrm{N}=448$

$42,278.44$

$1,193,253.66$

$124,588.61$

$145,352.60$

1.17

$\mathrm{n}=32$

$44,174.19$

$872,024.10$

$142,487.10$

1.14

\begin{tabular}{|c|c|c|c|c|c|c|}
\hline \multicolumn{7}{|c|}{ Type of international commercial insertion } \\
\hline $\begin{array}{l}\text { X12: Foreign trade of high } \\
\text { complexity goods }\end{array}$ & 416 & 9.15 & $10,618.07$ & $1,711.90$ & $2,150.47$ & 1.26 \\
\hline \multicolumn{7}{|l|}{ B) Realized efforts } \\
\hline $\begin{array}{l}\text { X13: Public Expenditure on } \\
\text { education }\end{array}$ & 527 & 0.58 & 8.24 & 3.82 & 1.21 & 0.32 \\
\hline $\begin{array}{l}\text { X14: State Budget for Science } \\
\text { and Technology }\end{array}$ & 156 & 0.00 & 1.51 & 0.17 & 0.20 & 1.19 \\
\hline
\end{tabular}




\begin{tabular}{|c|c|c|c|c|c|c|}
\hline \multicolumn{7}{|c|}{ Acquisition of external knowledge } \\
\hline $\begin{array}{l}\text { X15: Foreign Direct Invest- } \\
\text { ment (FDI) }\end{array}$ & 544 & -53.10 & $2,562.09$ & 242.85 & 245.26 & 1.01 \\
\hline $\begin{array}{l}\text { X16: Imports of high com- } \\
\text { plexity products }\end{array}$ & 416 & 0.06 & 0.74 & 0.36 & 0.16 & 0.44 \\
\hline X17: Interstate immigration & 544 & 2.63 & 34.18 & 9.50 & 5.79 & 0.61 \\
\hline $\begin{array}{l}\text { X18: International immigra- } \\
\text { tion }\end{array}$ & 544 & 0.08 & 4.90 & 1.53 & 1.06 & 0.70 \\
\hline \multicolumn{7}{|l|}{ C) Results achieved } \\
\hline Y1: Patents granted & 416 & 0.00 & 53.10 & 3.13 & 7.94 & 2.54 \\
\hline Y3: Scientific Publications & 448 & .15 & 20,901 & 974.55 & $2,395.73$ & 2.45 \\
\hline $\begin{array}{l}\text { Scientific Publications (per } \\
\text { NRS) }\end{array}$ & 448 & .1 & 3.3 & 1.59 & 0.66 & 0.42 \\
\hline $\begin{array}{l}\text { Y5: Complexity products } \\
\text { (exported) }\end{array}$ & 416 & 0.0007 & 0.80 & 0.21 & 0.20 & 0.92 \\
\hline
\end{tabular}

Source: Own elaboration (STATA 14).

\section{Econometric Model: Specifications}

First, it is important to emphasize that the parameters associated with the regression models resulting in this section are evaluated using a data panel set for the 32 Mexican entities over 13 years $^{6}$. Therefore, as pointed out by Stern, Porter \& Furman (2000), these estimates may depend on the variation of the cross section, that is, the variation of time series, or space (countries) or both. It is then perceived that the most precise approach to model the individual character of each entity is through the panel model with fixed individual and temporal ${ }^{7}$ effects.

The fixed-effect model assumes that heterogeneity among individuals can be captured through differences in the constant term, which is equivalent of assuming these variations as deterministic. Thus, fixed effect means $\operatorname{cov}\left(\mathrm{X}_{\mathrm{i}}, \mathrm{Z}_{\mathrm{i}}\right) \neq 0$. Since these are non-observed variables, the individual heterogeneity is collected through a set of $\mathrm{n}-1$ dichotomous variables ( $\mathrm{d}_{\mathrm{i}}$ ), whose associated coefficients $\mu_{i}$ indicate the differences individual with respect to the reference individual and are estimated together with the slopes $\mathrm{k}$. Therefore, it is reflected that the main objective of the panel data models is precisely to capture the unobservable

\footnotetext{
${ }^{6}$ Given the existence of gaps in the first 4 years of the dependent variables (patents granted) for inferential statistics, we decided to consider a time series from 2004 to 2016, in order to have a balanced data panel. Therefore, we decided not to assume lags.

${ }^{7}$ Individual effects: usually invariant over time. They represent the direct impact of all the individual characteristics that are not observable and invariant over time over Yit. Temporal effects: that can be assumed invariant between individuals; each period has specific unobservable effects. Individual and time effects: changing effects that can be both deterministic and stochastic (Perazzi \& Merli, 2013).
} 
heterogeneity, which is ignored in the traditional regression models and that affects the estimation of the effects of the variables x above y (Perazzi \& Merli, 2013).

To define econometric models with panel-type data, initially (as a first stage) the Breusch-Pagan test, also called the Lagrange Multiplier, is run. The test consists of performing the auxiliary regression indepit $=$ depit $+u i+e i t$.

The null hypothesis is $\sigma_{u}^{2}=0$ with a contrast ${ }^{8} \mathrm{chi}^{2}$. If the test value is low (p-value greater than 0.95) the null hypothesis is confirmed and an Ordinary Least Squares model (OLS) is better. If the test value is high (p-value less than 0.05) the null hypothesis is rejected and it is better to choose a nested model. In other words, if the null hypothesis is rejected, it would imply that there is indeed an unobservable component of the variance associated with each individual (Aparicio \& Márquez, 2005; Mayorga \& Muñoz, 2008; Labra \& Torrecillas, 2014; Torres, 2007; Montero, 2011).

As a second stage, it is necessary to compare the estimates of the fixed-effect model and the random-effects model. For this, the Hausman test is performed, in which, if systematic differences are found (the null hypothesis of equality is rejected, that is, a high-test value and a low p-value, less than 0.05), is obtained. Then it can be assumed that there is still a correlation between the error and the $\operatorname{cov}\left(\mathrm{X}_{\mathrm{it}}, \mathrm{Z}_{\mathrm{i}}\right) \neq 0$ regressors and it is preferable to choose the fixed effects model to the random effects model.

In a third step, Aparicio \& Márquez (2005), point out that it is convenient to perform the Parm test, to verify if, it is also possible to add temporary dichotomous variables to the model (with notation $\delta_{t} t_{t}$ ), that is, a YEAR_DUMMY for each year in the sample, they capture events common to all states during one period or another. Where the null hypothesis is that $\mathrm{t}_{1}=\mathrm{t}_{2}=\cdots=\mathrm{t}_{t}=0$, in that sense, the $\mathrm{p}$-value of the $\mathrm{F}$ test indicates that if we reject the null hypothesis, it could be said that the temporary dichotomous variables are jointly significant and belong to the model, otherwise the $\mathrm{H}_{0}$ is accepted, which would imply that the temporary fixed effects would be statistically insignificant.

Finally, it is required to run the Wooldridge and Wald tests, in which, if we reject the null hypothesis, we show problems of autocorrelation and heteroscedasticity, which should be solved together with the Panel Corrected Standard Errors (PCSE) model.

${ }^{8}$ The prob $>$ chi2 $>0.05$ 


\section{Econometric Model: Results}

From the outset, the correlation matrix between independent variables is elaborated (table 3) in order to avoid multicollinearity problems in the model.

Table 3

Matrix correlation

\begin{tabular}{|c|c|c|c|c|c|c|c|c|c|c|c|c|c|c|c|c|c|c|}
\hline VAR & $\mathrm{X1}$ & $\mathrm{X} 2$ & $\mathrm{X} 3$ & $\mathrm{X} 4$ & $\times 5$ & $\mathrm{X6}$ & $\mathrm{X} 7$ & $X 8$ & x9 & $\mathrm{X} 10$ & X11 & $\mathrm{X} 12$ & $\mathrm{X13}$ & X14 & $\mathrm{X} 15$ & X16 & $\mathrm{X} 17$ & $\mathrm{X} 18$ \\
\hline $\mathrm{X1}$ & 1.0 & & & & & & & & & & & & & & & & & \\
\hline $\mathrm{X} 2$ & $-168^{\prime \prime \prime}$ & 1.0 & & & & & & & & & & & & & & & & \\
\hline $\mathrm{X3}$ & $.637^{* *}$ & $.211^{* *}$ & 1.0 & & & & & & & & & & & & & & & \\
\hline$X 4$ & $.474^{* *}$ & $.116^{\text {*t* }}$ & $.815^{* t}$ & 1.0 & & & & & & & & & & & & & & \\
\hline $\mathrm{X5}$ & $.390^{\prime \prime}$ & $.205^{\text {*t }}$ & $.578^{\text {*t }}$ & $.604^{\prime \prime \prime}$ & 1.0 & & & & & & & & & & & & & \\
\hline $\mathrm{X6}$ & $.346^{* *}$ & $.199^{* *}$ & $.513^{\text {t" }}$ & $.514^{* *}$ & $.350^{* t}$ & 1.0 & & & & & & & & & & & & \\
\hline X7 & $.437^{\mathrm{kt}}$ & -0.1 & $.607^{* k}$ & $.667^{\text {t* }}$ & $.427^{\text {t* }}$ & $.465^{* *}$ & 1.0 & & & & & & & & & & & \\
\hline$X 8$ & $.638^{* 1+}$ & 0.1 & $.569^{*+1}$ & $.442^{* *}$ & $.406^{\text {*t }}$ & $.738^{* *}$ & $.483^{* \prime}$ & 1.0 & & & & & & & & & & \\
\hline x9 & $.412^{* *}$ & 0.0 & -0.1 & $-.184^{* *}$ & -0.1 & 0.0 & $-.180^{* * *}$ & $.183^{\mathrm{*}}$ & 1.0 & & & & & & & & & \\
\hline $\mathrm{X10}$ & $.264^{* \prime}$ & $.387^{* *}$ & $.381^{* *}$ & $.270^{* t}$ & $.375^{* t}$ & $.535^{*}$ & $.259^{* *}$ & $.671^{* t}$ & 0.0 & 1.0 & & & & & & & & \\
\hline $\mathrm{X11}$ & $.122^{\prime \prime}$ & 0.0 & 0.0 & 0.1 & $.362^{* t}$ & $.097^{*}$ & $.116^{*}$ & 0.07 & 0.02 & $.321^{* *}$ & 1.0 & & & & & & & \\
\hline $\mathrm{X12}$ & $.501^{* *}$ & $.106^{*}$ & $.288^{* *}$ & 0.1 & $.387^{* *}$ & 0.1 & $.153^{* *}$ & $.446^{* *}$ & $.442^{* *}$ & $.209^{* *}$ & 0.01 & 1.0 & & & & & & \\
\hline X13 & $.359^{* *}$ & $-.142^{* *}$ & $.564^{* *}$ & $.731^{* *}$ & $.258^{* t}$ & $.308^{\prime \prime}$ & $.646^{* *}$ & $.189^{* *}$ & $-.145^{\mathrm{N}}$ & 0.0 & $.310^{* t}$ & 0.0 & 1.0 & & & & & \\
\hline X14 & $.183^{\circ}$ & -0.029 & -0.019 & -0.094 & 0.046 & -0.034 & -0.032 & 0.084 & 0.070 & $.175^{\circ}$ & $.452^{\prime \prime \prime}$ & 0.056 & 0.042 & 1.000 & & & & \\
\hline $\mathrm{X15}$ & $.478^{\text {*t }}$ & -0.1 & $.268^{* * t}$ & $.187^{\text {t* }}$ & $.187^{* t}$ & $.360^{* t}$ & $.229^{* t}$ & $.473^{\text {*t }}$ & $.374^{4 t}$ & $.198^{* *}$ & 0.1 & $.327^{\text {t* }}$ & $.181^{* t+}$ & 0.0 & 1.0 & & & \\
\hline X16 & $.192^{* \prime \prime}$ & $.140^{* *}$ & $.226^{* *}$ & 0.0 & $.238^{* *}$ & 0.0 & $-.100^{*}$ & 0.1 & $.226^{\prime \prime}$ & 0.0 & 0.0 & $.468^{\prime \prime}$ & $-228^{* t *}$ & 0.0 & 0.0 & 1.0 & & \\
\hline X17 & $.337^{* \prime}$ & $-459^{* \prime \prime}$ & 0.0 & 0.0 & $-.237^{* \prime}$ & $.151^{\prime \prime}$ & $.166^{* \prime}$ & $.143^{\mathrm{m}}$ & $.268^{\prime \prime}$ & $-.177^{* *}$ & $.133^{* \prime}$ & $-.137^{\prime \prime}$ & 0.1 & -0.1 & $.328^{\prime \prime}$ & $-.158^{\prime \prime \prime}$ & 1.0 & \\
\hline X18 & $.239^{*}$ & $-.202^{* *}$ & $-.100^{\star}$ & $-.188^{\text {t* }}$ & $-.197^{* t}$ & $-116^{* t}$ & $-.124^{* t}$ & $.133^{* t}$ & $.371^{\prime \prime}$ & -.256 & $-180^{* t+}$ & $.291^{*}$ & 0.0 & \begin{tabular}{l|}
0.1 \\
\end{tabular} & $.145^{* t}$ & $\begin{array}{l}-0.1 \\
\end{array}$ & $.109^{*}$ & 1. \\
\hline
\end{tabular}

Note: ** The correlation is significant at the 0.01 level (bilateral), ${ }^{*}$ The correlation is significant at the 0.05 level (bilateral). Source: Own elaboration (STATA 14).

Under said treatment, an appreciable linear correlation appears between:

- The literacy rate $\left(\mathrm{X}_{1}\right)$ with the secondary enrollment rate $\left(\mathrm{X}_{3}\right)$ and with telephone lines $\left(\mathrm{X}_{8}\right)$. It was decided to eliminate the first two.

- The secondary enrollment rate $\left(\mathrm{X}_{3}\right)$ with the tertiary enrollment rate $\left(\mathrm{X}_{4}\right)$ and cellular enrollment $\left(\mathrm{X}_{7}\right)$. It was decided to eliminate the first two.

- The tertiary enrollment rate $\left(X_{4}\right)$ with graduates in STI $\left(X_{5}\right)$, cell phones $\left(X_{7}\right)$ and Public Expenditure in education $\left(\mathrm{X}_{13}\right)$. It was decided to eliminate the first three.

- Researchers in the NRS $\left(\mathrm{X}_{7}\right)$ with telephone lines $\left(\mathrm{X}_{8}\right)$.It was decided to eliminate the second variable.

Derived from the above, it was decided to design a base of the regression model for each dependent variable. As such, the independent variables of the model include indicators of the available base and of the efforts made but avoid multicollinearity problems. The basis of the model can be seen in table 4 . 
Table 4

The basis of the model

\begin{tabular}{ll}
\hline DIMENTIONS & RESULTADOS LOGRADOS DE LA CAPACIDAD TECNOLÓGICA \\
\hline & $\mathrm{X}_{2}$ Primary enrollment rate \\
& $\mathrm{X}_{6}$ Researchers NRS (Ln) \\
& $\mathrm{X}_{7}$ Cell phones (Ln) \\
& $\mathrm{X}_{9}$ Electricity consumption (Ln) \\
& $\mathrm{X}_{11}$ GDP per capita (Ln) \\
& $\mathrm{X}_{12}$ Foreign trade of high complexity goods (Ln) \\
& $\mathrm{X}_{13}$ Public Expenditure on education (Ln) \\
& $\mathrm{X}_{15}$ Foreign Direct Investment (FDI) (Ln) \\
& $\mathrm{X}_{16}$ Imports of high complexity products \\
& $\mathrm{X}_{17}$ Interstate immigration (Ln) \\
& $\mathrm{X}_{18}$ International immigration (Ln) \\
REALIZED EFFORTSESE & \\
\hline Nota: Ln = Natural logarithm &
\end{tabular}

Source: Own elaboration.

\section{Data panel model with individual and temporary fixed effects}

Considering then the previous specifications, the data panel model with fixed individual and temporal effects is denoted in the following way:

$$
Y_{i t}=\beta_{0}+\sum_{i=1}^{N-1} \mu_{i} d_{i}+\sum_{\substack{t=1 \\ \mathrm{i}=1, \ldots, \mathrm{N}}}^{T-1} \delta_{t} t_{t}+\sum_{k=1}^{k} \beta_{k} X_{k i t}+e_{i t}
$$




\section{Donde:}

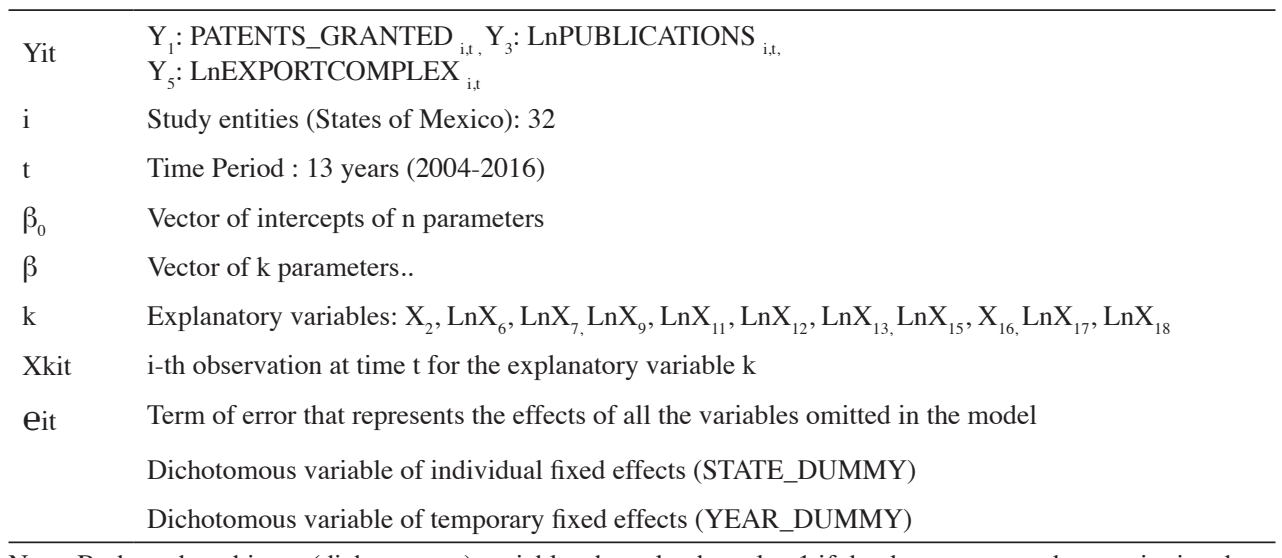

Note: Both and are binary (dichotomous) variables that take the value 1 if the data corresponds to entity $i$ and zero in other case. Whereas, y reflect the fixed individual and temporal effects of the entity i respectively. (Ln) denotes Natural Logarithm. Source: Own elaboration

Considering equation (2), we run the regressions for each dependent variable. Where it is shown in table 5, the coefficients marked in bold were statistically significant, which allows us to make precise inferences about the impacts of the base available and the efforts made on the results achieved in terms of technological capacity.

Table 5

Results: Regression models with fixed effects

\begin{tabular}{|c|c|c|c|}
\hline Variables & $\begin{array}{c}\mathrm{Y}_{1} \\
\text { PATENTS GRANTED } \\
\end{array}$ & $\begin{array}{c}\mathrm{Y}_{3}(\mathrm{Ln}) \\
\text { SCIENTIFIC PUBLICATIONS } \\
\end{array}$ & $\begin{array}{c}\mathrm{Y}_{5} \\
\text { COMPLEXITY PRODUCTS }\end{array}$ \\
\hline \multicolumn{4}{|l|}{ AVAILABLE BASE } \\
\hline \multicolumn{4}{|l|}{ Human Resources } \\
\hline $\mathrm{X}_{2:}$ Primary enrollment rate & $\begin{array}{c}0.090 \\
(0.061)\end{array}$ & $\begin{array}{l}-0.016 * \\
(0.004)\end{array}$ & $\begin{array}{c}0.014 * * \\
(0.008)\end{array}$ \\
\hline $\mathrm{X}_{6:}$ Researchers NRS (Ln) & $\begin{array}{c}0.512 * * * \\
(0.291)\end{array}$ & $\begin{array}{l}1.163 * \\
(0.057)\end{array}$ & $\begin{array}{c}0.091 \\
(0.083)\end{array}$ \\
\hline \multicolumn{4}{|l|}{ Infrastructure } \\
\hline $\mathrm{X}_{7:}$ Cell phones (Ln) & $\begin{array}{c}-0.854 * * \\
(0.405)\end{array}$ & $\begin{array}{l}-0.044 \\
(0.039)\end{array}$ & $\begin{array}{l}-0.052 \\
(0.076)\end{array}$ \\
\hline $\mathrm{X}_{9:}$ Electricity consumption (Ln) & $\begin{array}{c}-1.504 * * \\
(0.696)\end{array}$ & $\begin{array}{c}-0.115^{* * * *} \\
(0.084)\end{array}$ & $\begin{array}{c}0.867 * * \\
(0.351)\end{array}$ \\
\hline \multicolumn{4}{|c|}{ Complexity of technological demand } \\
\hline $\mathrm{X}_{11:}$ GDP per capita $(\mathrm{Ln})$ & $\begin{array}{c}1.639 \\
(1.487)\end{array}$ & $\begin{array}{l}-0.201 \\
(0.139)\end{array}$ & $\begin{array}{c}0.288 \\
(0.454)\end{array}$ \\
\hline
\end{tabular}




\begin{tabular}{|c|c|c|c|}
\hline \multicolumn{4}{|l|}{ Type of international commercial insertion } \\
\hline $\mathrm{X}_{12:}$ Foreign trade of high complexity goods (Ln) & $\begin{array}{r}-0.074 \\
(0.272) \\
\end{array}$ & $\begin{array}{l}-0.006 \\
(0.029) \\
\end{array}$ & $\begin{array}{l}0.630 * \\
(0.094)\end{array}$ \\
\hline \multicolumn{4}{|l|}{ REALIZED EFFORTS } \\
\hline $\mathrm{X}_{13:}$ Public Expenditure on education (Ln) & $\begin{array}{l}2.113^{* *} \\
(0.971)\end{array}$ & $\begin{array}{l}-0.321 * \\
(0.084) \\
\end{array}$ & $\begin{array}{c}0.047 \\
(0.202)\end{array}$ \\
\hline \multicolumn{4}{|l|}{ Acquisition of external knowledge } \\
\hline $\mathrm{X}_{15:}$ Foreign Direct Investment (FDI) (Ln) & $\begin{array}{r}-0.001 \\
(0.190)\end{array}$ & $\begin{array}{c}0.010 \\
(0.009)\end{array}$ & $\begin{array}{l}-0.002 \\
(0.029)\end{array}$ \\
\hline $\mathrm{X}_{16:}$ Imports of high complexity products & $\begin{array}{l}2.909^{*} \\
(1.129)\end{array}$ & $\begin{array}{c}0.078 \\
(0.123)\end{array}$ & $\begin{array}{l}-0.459 \\
(0.377)\end{array}$ \\
\hline $\mathrm{X}_{17:}$ Interstate immigration (Ln) & $\begin{array}{l}-0.383 \\
(0.916)\end{array}$ & $\begin{array}{l}0.745^{*} \\
(0.177)\end{array}$ & $\begin{array}{l}-0.255 \\
(0.250)\end{array}$ \\
\hline $\mathrm{X}_{18:}$ International immigration (Ln) & $\begin{array}{r}1.104 * * \\
(0.580) \\
\end{array}$ & $\begin{array}{l}-0.107 \\
(0.085)\end{array}$ & $\begin{array}{l}-0.033 \\
(0.200) \\
\end{array}$ \\
\hline \multicolumn{4}{|l|}{ NOTE } \\
\hline Constant & $\begin{array}{l}-29.816 * * * \\
(19.983)\end{array}$ & Omitted & $\begin{array}{c}0.818 \\
(5.411)\end{array}$ \\
\hline Observations & 340 & 340 & 340 \\
\hline States & 32 & 32 & 32 \\
\hline R-squared & 76.57 & 98.12 & 98.34 \\
\hline Test of significance & 0.0000 & 0.0000 & 0.0000 \\
\hline FIV mean & 2.07 & 2.07 & 2.07 \\
\hline Breusch and Pagan Test & 0.0000 & 0.0000 & 0.0000 \\
\hline Hausman test & 0.0000 & 0.0869 & 0.0000 \\
\hline Fixed Effects by states & Significant & Significant & Significant \\
\hline Testparm i.year & 0.9908 & 0.0000 & 0.0149 \\
\hline Fixed Effects by time & No Significant & Significant & Significant \\
\hline Wooldridge test & 0.5561 & 0.0000 & 0.5001 \\
\hline Modified Wald (heteroscedasticity) & 0.0000 & 0.0000 & 0.0000 \\
\hline Optimal model & PCSE Model & PCSE Model & PCSE Model \\
\hline
\end{tabular}

ADDITIONAL NOTES: Standard Errors are denoted in parentheses (Standard Error). PCSE = Model of standard errors corrected for panel. $(\mathrm{Ln})=$ Natural Logarithm. Average FIV = Variation Inflation Factor (when the FIV value is greater than 5 , multicollinearity problems may be suspected). Significance of:

$* * * \mathrm{p} \leq 0.10 * * \mathrm{p} \leq 0.05 \quad * \mathrm{p} \leq 0.01$

Source: Own elaboration (STATA 14). 
Translating the coefficients as elasticities, we show an increase of $1 \%$ in the NRS research staff of which is related to the increase of 0.51 in the granted patents. On the other hand, the percentage of granted patents has an inverse relationship with the consumption of electrical energy (as a proxy for the diffusion of old technologies). That is, an increase of $1 \%$ in the first one is related to decreases of $1.5 \%$ in the second variable. In addition, increases of $1 \%$ in educational spending are linked to elastic increases of $2 \%$ over patents granted. While increases of $1 \%$ in international immigration are related to increases in patents granted with a similar percentage. The variable with the highest elasticity over the granted patents, turns out to be the one named - imports of highly complex products (with 3\%)- which reinforces the premise that "a common feature of developing countries is that local technological capacity in these countries is generally low. Therefore, it becomes indispensable to take into account the role of the global force and especially the imports of technology"(Chinaprayoon, 2007, p.32).

At the same time, the increase of $1 \%$ in primary enrollment, in electricity consumption and in educational spending, has a relation with the decrease of scientific publications in a marginal percentage of $0.016 \%, 0.115 \%$ and $0.32 \%$ respectively. While the $1 \%$ increase in state immigration is linked to the $0.74 \%$ increase in scientific publications, which reinforces the premise that "the mobility of Know How at a national and regional level is important because it is faster and cheaper to move a brain than to create it” (Hausmann, 2017). Finally, the variable with the greatest impact (elasticity) on scientific publications, turns out to be the NRS researchers' platform (with $1.16 \%$ ), this in turn is logical and predictable, though, the contribution itself is an estimation of the elasticity of that relationship.

Finally, with respect to exports of complexity, the only indicators of technological capacity that were statistically significant were: primary enrollment $(0.014 \%)$, electricity consumption $(0.867 \%)$ and foreign trade of high-tech goods $(0.630 \%)$. Consequently, since exports and imports encompass the exchange of embodied information, the premise highlighting the dynamics between both variables being an elementary factor for the generation of technological outputs is reinforced (Hidalgo, 2017).

\section{Extended interpretations of the results}

The interpretation of the results leads us in two directions: highlighting the determinants of the technological capacity to produce: 1) scientific (publications) and 2) techno-scientific (patents and exports) of the region. Thus, taking into account that beyond the calculation, the contextualization and translation of the empirical findings is a priority. 


\section{Determinants of the technological capacity to crystallize scientific products}

The variables (of the technological capacity) that show the greatest impact on the generation of scientific publications are the number of researchers (in the available database) and mobility among Mexican states.

Even though for this research study, we did not count on the variable of the state budget of science and technology ${ }^{9}$ for the whole panel, it is a relevant finding that mobility as part of the efforts made is statistically significant. This finding is consistent with the idea of Hausmann \& Nedelkoska (2018, p.119), "there are positive human capital externalities from migration". While this phrase may generate a debate on the relevance and mechanisms for the formation of human capital, it should not be underestimated how important this recipe (migration) could be for short- and medium- term economic development (Urbina \& Sierra, 2015).

On the other hand, it is not surprising that the number of researchers is a trigger for the generation of publications. The contribution of this document consists in demonstrating the elasticity of this relationship $\left(\Delta 1 \% \mathrm{X}_{6} \equiv \Delta 1.16 \% \mathrm{Y}_{3}\right)$.

Putting the previous findings into context, according to the ranking of Scimago Journal (2018), the number of publications in Mexico is in 29th place out of a total of 239 countries. That places it in second place in all of Latin America only behind Brazil. The above seems to be "good" news at the national level, however, when productivity is observed at the regional level, the coefficient of variation of the publications made by the researchers is the second highest, therefore, the average is not a reliable indicator. The fact that individual fixed effects are statistically significant also shows that the step variable of publications (the order of origin for each state, denoted by $\mu \_i$ ) is clearly different and therefore the ability to crystallize scientific products is heterogeneous and it is subject to a small group of states. While the significance of temporal effects also denotes that a dependence on a previous trajectory also counts.

It is critical to generate differentiated policies -intrinsic and extrinsic programs and incentives that promote the repatriation of talent- to avoid brain drain and encourage the mobility of researchers, along with attracting them to regions in need of scientific talent and research. It is clearly imperative as this empirical study of the evidence of has shown.

\section{Determinants of the technological capacity to crystallize the techno-scientific products}

The variables (of technological capacity) that show a greater impact with elastic effects ${ }^{10}$ on the generation of patents are: imports of highly complex products $(2,909 \%)$, education

\footnotetext{
${ }^{9}$ It is assumed as a natural and essential determinant of technological capacity. However, given the limited public availability of information, it is impossible to test it within our data panel.
} 
spending $(2,113 \%)$, international immigration $(1,104 \%)$ and the consumption of electrical energy with an inverse relationship $(-1,504 \%)$.

In our research, we show with empirical evidence that the imports of high complexity products are determinants for the technoscientific products (concretely granted patents). This is consistent with the basic wedge development model, in which, according to Oizumi (2014), the less developed or technologically delayed (persecuting) regions start importing foreign products from more economically advanced countries, and initially this contributes to the development of the local industry through the demonstration of learning by use effect.

The foregoing is linked to the result that reveals that the foreign trade of highly complex goods is also a determinant (inelastic) of highly complex exports. Therefore, according to Hausmann et al (2014), it is useful to analyze international trade, since thinking about the export of products in terms of the crystallized imagination allows us to see that we live in a world in which some entities are net importers of imagination, while others are net exporters.

In fact, the composition of the exports of an entity shows us knowledge information and the know how that lives in their population. Therefore, it is not surprising that both imports of highly complex goods and foreign trade of highly complex goods are trigger elements of the results achieved in terms of technological capacity. Despite that, the contribution of Mexican scientists consists in demonstrating the (in) elasticity of this relationship $\left(\Delta 1 \% \mathrm{X}_{16}\right.$ $\left.\equiv \Delta 2.909 \% \mathrm{Y}_{1}\right)$ y $\left(\Delta 1 \% \mathrm{X}_{12} \equiv \Delta 0.630 \% \mathrm{Y}_{5}\right)$.

Therefore, our research raises the question about: when does the trade balance between entities (the monetary value of exports minus imports) have the opposite effect of the balancing of their imaginations? Finding examples of this situation using the antagonistic states is revealing. That is, given that the fixed effects were statistically significant, it is possible to recognize that the state with the lowest variable step $\left(\mu_{\mathrm{i}}\right)$-ordered to the origin- (see figure 1), with respect to $\mathrm{Y}_{1}$ was the state of Campeche $\left(\mu_{4}=\right.$ Iedo_4 $\left.=-3.55\right)$, while the highest fixed effect captured $\left(\mu_{\mathrm{i}}\right)$ was the state of Nuevo León $\left(\mu_{19}=\right.$ Iedo_19 $\left.=16.63\right)$. Then, according to the Atlas of Complexity (2018), in 2014 Campeche exported US\$ 16.7 billion worth of products to the U.S.A., mainly minerals, specifically crude oil. In that same year the value of imports from the U.S.A to Campeche was 277.3 million dollars, in particular cars and machinery. Campeche had a comfortable trade balance with U.S.A with 16.4 billion dollars of exports. But the balance of imagination is clearly negative because Campeche did not incorporate much imagination into the exported products and this state imported a large amount of imagination incorporated into the products purchased.

The low capacity of the state of Campeche to generate patents is also reflective of a negative balance of imagination.

\footnotetext{
${ }^{10}$ That is to say that before changes of $1 \%$ in the independent variable, increases of greater proportion of the dependent variable is expected.
} 
Conversely, in that same year, Nuevo León exported US \$ 24.6 billion worth of products to the U.S.A, mainly machinery, cars and electronics, while the value of U.S.A imports to Nuevo León was 18.1 billion dollars, especially in the form of machinery, metals and chemicals. In this case, although the trade balance is not as wide as that of Campeche, it is also positive with an amount of 6.5 billion dollars, which implies the commercial balance of Campeche is $252 \%$ higher than the trade balance of Nuevo León. Even so, the balance of imagination of Nuevo León is vastly superior to that of Campeche, so that while Campeche exports only crude oil to the United States, Nuevo León exports a series of diverse products that have to do with machinery, electronics and cars.

The high capacity of the state of Nuevo León to generate patents and exports of complexity is also reflective of a positive balance of imagination.

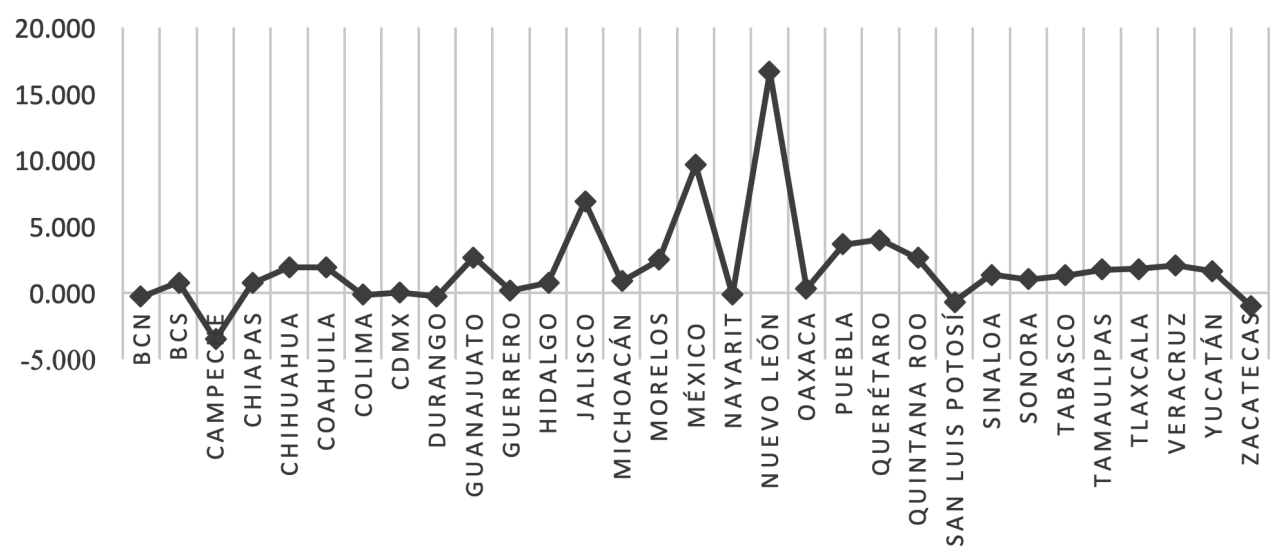

Figure 1. Fixed effects for $\mathrm{Y}_{1}$ : variable $\left(\mu_{\mathrm{i}}\right)$

Source: Own elaboration based in the econometric model.

The classic economic concepts, such as the trade balance between two countries or entities, seem incomplete once we reinterpret the products as crystals of imagination. When we begin to see products as the embodiment of human imagination, we realize that there is an alternative to the trade balance: the balance of imagination, which refers to the exchange of imagination that we transport implicitly in the nuclei of the atoms that we sell and buy (Hidalgo, 2017).

In parallel, international immigration reflects an elastic behavior in the generation of granted patents (of a nation's citizens). Hence, it is important to consider the premise of Hausmann, Obach \& Santos (2016), which concludes that if immigrants bring a group of skills and if those skills are spread among local workers, productivity can increase, and as a 
result also increase the salaries. Therefore, according to Hausmann \& Nedelkoska (2018), the talent that comes from another country, whether from foreigners or from returning migrants, represents an engine for accelerating the growth of an economy. Moreover, in addition to boosting productivity, talent transfer helps to reduce inequality.

Given the above, it is useful to ask what socioeconomic factors will attract the arrival of new immigrants. The results of a study by García \& López (2004) show that statistically the GDP per capita (proxy of the stock of knowledge) and the ratio of foreigners (as a proxy of the effect of the networks) are determined at the time of deciding the destination country by future immigrants. This suggests that the immigration of talent is attracted to places where there is a high accumulation of knowledge. However, the effect of local networks that are linked with international nodes, also acts as an anchor when it comes to seducing brains into a region. In contexts such as the Mexican one where states with a smaller stock of knowledge or short technological trajectories could, despite this shortage, still attract foreign talent through the generation of networks of researchers, entrepreneurs and like talent, to name a few.

With regard to spending on education as a determining factor to crystallize the techno-scientific products, we find that for Hidalgo (2017), overly optimistic economic models have tended to assume that demand and incentives are enough to stimulate the production of any product, in this case patents, as a product of research. Nevertheless, incentives serve to motivate intermediaries and merchants, but the creators - the inventors - who provide what is invented / marketed, need more than an incentive to create something. They need to know how to do it. Fundamentally, inventors initially need to learn how to be inventors and to be shaped by the thirst for knowledge and innovation, particularly in STEM ${ }^{11}$ disciplines. The home of learning in these areas is at heart undoubtedly the educational institutions. Spending on education is always investing in the future. In Mexico, the situation is not just to spend more, but fundamentally to spend better.

It is also important to infer what is related to the consumption of electrical energy as a proxy of the diffusion ${ }^{12}$ of old technologies. That is, in the face of $1 \%$ increases among in the consumption of electric power (Gigawatts-hour) per 100 inhabitants, we would expect decreases of $1,504 \%$ in the output of granted patents. In other words, as the diffusion of old technologies diminishes, the number of patents granted will be less affected. The above is clear, if we recognize that to crystallize the technological products (in this case, patents), it will be required to diffuse new technologies to a greater extent. Thus, from the point of view of economic policy, according to Escot \& Galindo (1997), it would be ideal to facilitate the

\footnotetext{
${ }^{11}$ STEM is an acronym in English for Science, Technology, Engineering and Mathematics.

12 The effect of diffusion on productivity, therefore, occurs both through the purchases of machinery, equipment and technologically advanced components -diffusion incorporated in equipment- as well as through the simple resource of "borrowing" ideas, know-how and specialized knowledge -unincorporated diffusion- (Redes, 1996).
} 
process of technological diffusion by eliminating any obstacles or brake to the effective technological catch-up ${ }^{13}$ processes between leaders and followers. Otherwise, the progress of the poorest countries and the convergence among nations would be slowed down.

Additionally, Redes (1996, p.154) points out that "the condition -sine qua non-to take advantage of technological externalities is to have a certain capacity to absorb new technologies". This quote alludes to a double challenge in Mexico, first, to reduce the diffusion of old technologies by investing in technological learning, and then allowing that learning to build new absorption capacities that let us take ownership with a sophisticated understanding of emerging technologies.

Ultimately, we find that the diffusion of old and semi-new technologies ${ }^{14}$ is an inhibitor (elastic) of the generation of patents and a determinant (inelastic) of the generation of exports. This ambivalence may be attributed commercially to the diffusion of old technologies that can inhibit knowledge and know how, but sporadically maintains a high level of exports. In addition, this behavior of dependence towards the diffusion of old technologies has been found to be common in developing regions. Finally, it should be mentioned that the number of researchers was also a significant variable, although inelastic on the generation of patents. Clearly techno-scientific products are not achievable with the unique and isolated participation of scientists and researchers, given that "not all knowledge workers are professional workers and not all professional workers are knowledge workers" (Warhurst, 2008, p.75).

\section{Conclusions}

At the beginning of this study, we raised this question: What is the impact of the efforts made (inputs) and the available base (preconditions of development) on gains achieved technological capacity in Mexico? Therefore, the central objective was to recognize what factors are the drivers of technological capacity that serve to generate the techno-scientific products and to what extent do they (elasticity) impact the creation of patents, scientific publications and exports of complexity (see figure 2).

For this purpose, it was decided to adopt the quantitative method, making use of the panel data technique with fixed individual and temporal effects, based on the variables of technological capacity proposed by Cepal (2007) \& Hausmann \& Nedelkoska (2018), and collecting data

\footnotetext{
${ }^{13}$ The catch-up hypothesis implies that the greater the technological difference between the leader and the follower, and thanks to the diffusion of the internationally available technology, the greater the potential improvements that can be introduced in the productive processes of the follower country, and therefore, the potential growth of this front will also be greater than that of the leading country (Escot \& Galindo, 1997).

${ }^{14}$ Another indicator of the technological capacity that was statistically significant on the generation of patents is that of the number of cellular telephone users $(-0.85)$ as a proxy of the diffusion of new technologies.
} 
from various public sources. From the econometric estimation, it is found that: imports of highly complex products, spending on education, international mobility and the total number of researchers are the main determinants of technological capacity.

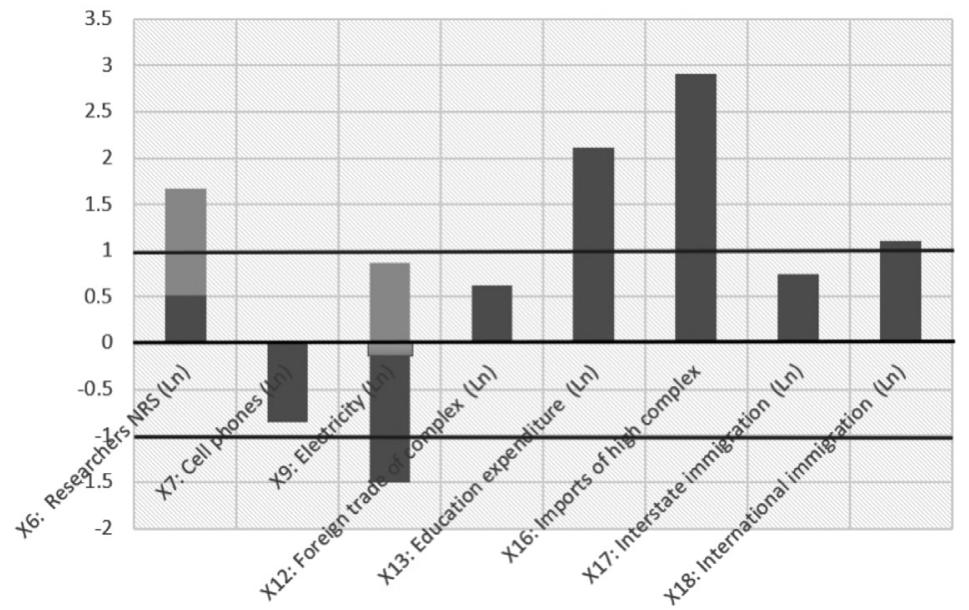

Figure 2. Impact (elasticities) of the efforts made (inputs) and the available base (preconditions of development on the results achieved in terms of technological capacity in Mexico

NOTE: Variables that exceed the upper and lower margin denote elasticity, while those that remain within the margin show inelastic behavior.

Source: Own elaboration based on econometric estimations.

Answering the central question of the research, then allows us to recognize what are the pieces that the policy makers can move with confidence of the expected impacts on the generation of patents, scientific publications and exports of technological content, that is, the techno-scientific products. "The measurement of technological capabilities is a subject that demands the elaboration of new works, in which the use of more sophisticated statistical tools is fundamental" (Torres, 2006, p.18). Paying attention to this claim, this research provides empirical evidence through the compilation of a battery of indicators as a data panel that for the first time is generated, grouped, and issued as an inferential statistical treatment in a transversal and longitudinal way to the variables relating to the Mexican technological capacity disaggregated by federal entities.

Furthermore, our mesoeconomic results (determinants of technological capabilities) show some convergences with other empirical studies at micro and macro level that confirm that:

- The science capabilities are more developed than the innovation capabilities, the latter do not generate neither catching up processes nor further stimulus for the development 
of a more problem-oriented science, which is the case of many developing countries, such as Mexico and many transition economies (Dutrénit, 2007, p.143)

- In Mexico, there are positive and significant correlations with Technology Index for variables such as age, education, skilled trained production workers, foreign ownership and exports. As far as exports are concerned, relevant firm-level characteristics include quality certification, technology received from foreign buyers, foreign inputs and R\&D. So, the process of building technological capabilities requires firms' continuous efforts and adequate linkages to absorb external knowledge (Molina \& Pietrobelli, 2012, p. 10).

- The level of trade liberalization (imports + exports/GDP), the patent stock and the expenditure on $R \& D$ are the most influential determinants of technological capacity in Latin America (Pérez, Gomez \& Lara, 2018).

- Successful sectors in Mexico in recent years have invested in technological capabilities and are focused on foreign sector, paying attention in the flow of imports, exports and foreign investments (Fujii, Torres, \& Salinas, 2013).

To sum up, we embarked on this study the intention of identifying what elements foment the ability to learn and innovate technology and what elements foment products and processes (technological capacity) generation.

\section{Reflections and discussions}

The basic idea is that capabilities represent abilities to do things, and technological capabilities reflect the mastering of technological activities (Morales \& Acevedo 2009). Therefore, the importance to develop more empirical evidence at micro, meso and macro level is required.

The main contribution of this work is that given the fixed effects were statistically significant, it is possible to recognize for each state its ordered to the origin with respect to "patents granted", in other words, we recognize the initial conditions and the heterogeneity related to its technological capabilities at a subnational level (mesoeconomic). This finding could be so useful, because according to Dutrénit (2007), the territories have initial conditions with quite high capabilities in both science and technology and also innovation, which do not exist in most developing regions, or with different types of imbalances. Therefore, it is required to rethink the type of policies that are required for the state's initial conditions.

The need to generate differentiated policies of Science, Technology and Innovation (STI) at sub-national and sub-state level is highlighted, given the high heterogeneity of regions and techno-scientific conditions.

There needs to be a tie between promoting certain productive activities in terms of their vocations with the generation of human resources. The research networks must be in accordance with the production vocations and strategic sectors of the regions. Since it is well known that 
"a successful transition process towards the deployment of strategic capabilities and leadership may depend on factors at three levels: micro, meso and macro" (Dutrénit, 2007, p.145). In this sense, Dutrénit \& Suárez (2018), refer that public participation experiences in Science, Technology and Innovation (STI) policy have gained significant interest in the last decades. It is recognized that due to the intensive changes in knowledge production (heterogeneity of actors and global links) it is required a more intensive participation of publics composed by the different communities in the STI policies arena, but also interaction and communication between these communities to design and execute successful policies. Also, the STI policy is a multistakeholder policy that involves a set of actors (i.e. government officials, businessmen, researchers, policymakers, civil society, NGOs, think-tanks, among others). It has a transversal nature, which requires considerable coordination efforts to plan and execute it with the rest of sectoral policies and ministers (energy, economy, agriculture, environment, health, home, security, among others). Each actor has their own vision of the priorities and direction that STI policy should take, and every community has its own agenda and different practices, codes, and channels of communication.

Additionally, Mian, Corona, \& Doutriaux (2010), remark that well as developing regions alike. As policy makers from emerging nations or territories grapple with new ideas on how to join the rapidly evolving knowledge-driven economy, they try to learn from the strategies that have been observed to be effective in developed nations to promote their economic development objectives. However, several other lesser developed regions of the world where new initiatives in innovation infrastructure development are underway need to be studied to enhance our understanding of the challenges posed by these transformations.

Finally, we highlight the need for in-depth studies of each state to propose differentiated technology policies. The identification of the weak areas of each entity in terms of technological capacity will suggest possible paths or routes for improvement, which should be complemented with in-depth studies of each case.

The present work, therefore, is an effort to influence the particular analysis of the STI but from a perspective that allows to correctly identify the technological capacities at the subnational level.

In Mexico, one of the great challenges is to promote regional development without generating greater regional imbalances and achieve a culture of innovation accompanied by strategies that persuade the triggers of technological capacity: Imports of technological content (having learning capabilities to retain technological understanding), education investment, international immigration of qualified people and the number of researchers. 


\section{References}

Albornoz, M. (2001). Política Científica y Tecnológica, Una visión desde América Latina. Iberoamericana de Ciencia, Tecnología, Sociedad e Innovación. Madrid. OEI.

ANUIES. (2016). Asociación Nacional de Universidades e Instituciones de Educación Superior. Available in: http://www.anuies.mx/informacion-y-servicios/informacion-estadistica-de-educacion-superior/anuario-estadistico-de-educacion-superior

Aparicio, J. and Márquez, J. (2005). Diagnóstico y especificación de modelos de panel en Stata 8. División de Estudios Políticos CIDE.

Arías, A. (2009). Mecanismos de aprendizaje y capacidades tecnológicas: el caso de una empresa del sector curtidor. INCEPTUM, Revista de Investigación en Ciencias de la Administración, 337-363.

ATLAS DE COMPLEJIDAD. (2017). Atlas Mexicano de Complejidad Económica. Available in: http://complejidad.datos.gob.mx/\#/downloads

ATLAS DE LA CIENCIA. (2017). Atlas de la Ciencia Mexicana. Available in:http://www.atlasdelacienciamexicana.org/es/sni_2013/Tabla\%2012.2\%20SNI.pdf

Baumert, T. and Heijs, J. (2013). Los determinantes de la capacidad innovadora regional: una aproximación econométrica al caso español: recopilación de estudios y primeros resultados. [Documentos de trabajo del IAIF; $\mathrm{n}^{\circ} 33$ ].

Bell, M. and Pavitt, K. (1995). The development of technological capabilities, en I. Haque (ed.), International Competitiveness: Interaction of the Public and the Private Sectors, Banco Mundial, Washington, pp. 69-101.

Bosier, S. (1995). La mesoeconomia territorial: interacción entre personas e instituciones: notas para gobiernos regionales. CEPAL.

CEPAL. (2007). Serie Estudios y Perspectivas. Indicadores de capacidades tecnológicas en América Latina. México: Naciones Unidas.

CFE. (2016). Comisión Federal de Electricidad. Available in: www.cfe.gob.mx, [Obtained 27 May 2016].

Chinaprayoon, C. (2007). Science, Technology and Innovation composite indicators for developing countries. Master dissertation. Georgia Institute of Technology.

CONAPO. (2017). Consejo Nacional de Población. Available in: http://www.conapo.gob.mx/es/CONAPO/Proyecciones_Datos

CTI indicadores. (2016). Indicadores de CTI en México. Available in: https://play.google.com/store/apps/details?id=org.foroconsultivo.ctindicadores\&hl=es_419

Dutrénit, G. (2007). The transition from building-up innovative technological capabilities to leadership by latecomer firms. Asian Journal of Technology Innovation, 15(2), 125-149. https://doi.org/10.1080/19761597.2007.9668640

Dutrénit, G., \& Suárez, M. (2018). Involving stakeholders in policymaking: tensions emerging from a public dialogue with knowledge-based entrepreneurs. Science and Public Policy, 45(3), 338-350. https://doi.org/10.1093/ scipol/scx043

Escot, 1. and Galindo, M. (1997). Difusión tecnológica y modelos de crecimiento. Facultad de CC.EE., Universidad Complutense de Madrid.

Faber, J. and Hesen, A. (2004). Innovation capabilities of European nations Cross-national analyses of patens and sales of product innovations, Research Policy, 1(33), 193-207.

FCCYT. (2016). Foro consultivo cientifico y tecnológico. Available in: http://www.foroconsultivo.org.mx/

Furman, J. and Hayes, R. (2004). Catching up or standing still? National innovative productivity among 'follower' countries, 1978-1999, Research Policy, Vol. 33, pp. 1329-1354.

Fujii, Dmitri, Torres, Luis D., \& Salinas, Ángel. (2013). Capacidades tecnológicas y el impacto del sector externo en la industria manufacturera mexicana. Economía: teoría y práctica, (38), 51-82. Recuperado en 02 de octubre de 2018, de http://www.scielo.org.mx/scielo.php?script=sci_arttext\&pid=S0188-338

Gans, J. and Hayes, R. (2009). Assessing Australia's Innovative Capacity: 2009 Update. Melbourne Business School and Intellectual Property Research Institute of Australia, the University of Melbourne. 
García, P. and López, G. (2004). Inmigración y bienestar: un estudio empírico para un panel de países de la OECD. Encuentros de Economía publica.

Hausmann, R. and Nedelkoska, L. (2018). Welcome Home in a Crisis: Effects of Return Migration on the Non-Migrants Wages and Employment, European Economic Review, 101(1), 101-132. DOI: https://doi.org/10.1016/j. euroecorev.2017.10.003.

Hausmann, R., Obach, J. and Santos, M. (2016). Las Zonas Económicas Especiales de Panamá: Difusión tecnológica vía mercado laboral. Working papers: Center for International Development at Harvard University.

Hausmann, R; Hidalgo, C; et al. (2014). The Atlas of Economic Complexity: Mapping paths to prosperity. MIT \& Harvard University.

Hernández, S. and Díaz, E. (2007). La producción y el uso del conocimiento en México y su impacto en la innovación: análisis regional de las patentes solicitadas. Análisis Económico, 22 (50), 185-217.

Hidalgo, C. (2017). El triunfo de la información: la evolución del orden: de los átomos a las economías. Barcelona: DEBATE.

Hu, M. \& Mathews, J. (2008). China's national innovative capacity. Research policy, 1465-1479.

IFT. (2016): Instituto Federal de Telecomunicaciones, Available in: http://www.ift.org.mx/

INEGI. (2016). Instituto Nacional de Geografía y Estadística. Available in: http://www.inegi.org.mx/sistemas/ bie/?idserpadre $=10200070 \#$ D10200070

INEGI. (2017). Instituto Nacional de Geografía y Estadística. Available in: http://www3.inegi.org.mx/sistemas/ sisept/default.aspx?t=etec $11 \& \mathrm{~s}=\mathrm{est} \& \mathrm{c}=19173$

Krammer, S. (2009). Drivers of national innovation in transition: Evidence from a panel of Eastern European countries. Research Policy, 38(5), 845-860. [respol.2009.01.022]. DOI: http://dx.doi.org/(...)j.respol.2009.01.022, 10.1016/j.respol.2009.01.022

Labra, R. and Torrecillas, C. (2014). Guía cero para datos de panel: Un enfoque práctico. Madrid. UAM-Accenture

Lall, S. (1992). Technological capabilities and industrialization, World Development, 20(2), 165-186.

López, M., Serrano, A., and García, G. (2011). Análisis de la capacidad de innovación regional: el caso español. Revista Venezolana de Gerencia, 16 (54), 209-232.

Mayorga, M. and Muñoz, E. (2008). La técnica de datos de panel una guía para su uso e interpretación. Costa Rica. DIE.

Mian, S., Corona, L., \& Doutriaux, J. (2010). Building knowledge regions in developing nations with emerging innovation infrastructure: evidence from Mexico and Pakistan. International Journal of Innovation and Regional Development, 2(4), 304. https://doi.org/10.1504/IJIRD.2010.037884

Monedero, J. (2015). Curso urgente de política para gente decente. PAIDÓS.

Montero. R. (2011). Efectos fijos o aleatorios: test de especificación. Documentos de Trabajo en Economía Aplicada. España: Universidad de Granada.

Dutrénit, G. (2007). The transition from building-up innovative technological capabilities to leadership by latecomer firms. Asian Journal of Technology Innovation, 15(2), 125-149. https://doi.org/10.1080/19761597.2007.9668640

Dutrénit, G., \& Suárez, M. (2018). Involving stakeholders in policymaking: tensions emerging from a public dialogue with knowledge-based entrepreneurs. Science and Public Policy, 45(3), 338-350. https://doi.org/10.1093/ scipol/scx043

Pérez, C; Gómez, D. \& Lara, G. (2018). Determinantes de la capacidad tecnológica en América Latina: Una aplicación empírica con datos de panel. Revista Economía: Teoría y Práctica - UAM. Disponible en: https://doi. org/10.24275/ETYPUAM/NE

Mian, S., Corona, L., \& Doutriaux, J. (2010). Building knowledge regions in developing nations with emerging innovation infrastructure: evidence from Mexico and Pakistan. International Journal of Innovation and Regional Development, 2(4), 304. https://doi.org/10.1504/IJIRD.2010.037884

Molina-Domene, M. A., \& Pietrobelli, C. (2012). Drivers of technological capabilities in developing countries: An econometric analysis of Argentina, Brazil and Chile. Structural Change and Economic Dynamics, 23(4), 504-515. https://doi.org/10.1016/j.strueco.2011.11.003 
Morales, R., \& Acevedo, V. (2009). Modelo de innovación Local- endógeno para el desarrollo de las zonas industriales del estado de Hidalgo. En A. Martínez, P. López, A. García, \& S. Estrada, Innovación y competitividad en la sociedad del conocimiento. México: Plaza y Valdés.

Oizumi, Y. (2004). Kaname Akamatsu y el modelo de desarrollo industrial japonés, Revista de Economía Mundial, 37, 201-224.

Pérez, C; Gómez, D. \& Lara, G. (2018). Determinantes de la capacidad tecnológica en América Latina: Una aplicación empírica con datos de panel. Revista Economía: Teoría y Práctica - UAM. Disponible en: https://doi. org/10.24275/ETYPUAM/NE

Perazzi, J. and Merli, G. (2013). Modelos de regresión de datos panel y su aplicación en la evaluación de impactos de programas sociales. Telos, 15 (1), 119-127.

REDES (1996). La difusión de tecnología. Redes, III (8), 119-161.

Riddel, M. and Schwer, R. (2003). Regional innovative capacity with endogenous employment: empirical evidence from the U.S, The Review of Regional Studies, 33(1), 73-84.

Romer, P. (1990). Endogenous Technological Change. Journal of Political Economy, 98 : S71 - S102.

Scimago Journal (2018). Country rankings. Available in: http://www.scimagojr.com/countryrank.php

SEP. (2016). Reportes Estadísticos del Cuestionario Financiamiento Educativo Estatal. Available in: http://www. planeacion.sep.gob.mx/cfee/

SIEMT. (2016): Sistema de Información Estadística de Mercados de Telecomunicaciones. Available in: http:// siemt.ift.org.mx/\#!prettyPhoto/14/

SNIE. (2016). Sistema Nacional de Información Estadística Educativa. Available in: http://www.snie.sep.gob.mx/ indicadores_pronosticos.html

Stern, S., Porter M., and Furman J. (2000). The determinants of innovation capability, USA, NBER Working Paper Series.

Torres, P. (2002). El impacto de la globalización tecnológica en la producción de ideas en México 1996-2000: un análisis regional, Tesis-El Colegio de la Frontera Norte, Tijuana, México.

Torres, A. (2006). Aprendizaje y construcción de capacidades tecnológicas. Journal of Technology Management \& Innovation. 1(5), 12-24.

Torres, R. (2007). Panel Data Analysis Fixes and Random Effects using Stata. USA. Princeton University.

Ulku, H. (2004). R\&D, Innovation, and Economic Growth: An empirical analysis. IMF Working Paper, 4-28

Urbina, E. and Sierra, J. (2015). La clave para el desarrollo es el know how. Ethos Laboratorio de Políticas Públicas.

Warhurst, C. (2008). The knowledge economy, skills and government labour market intervention. Policy Studies, 29(1), 71-86. doi:10.1080/01442870701848053. 